\title{
Pengaruh Substitusi Susu Kedelai dan Mocaf (Modified Cassava Flour) Terhadap Daya Terima, Kandungan Serat dan Nilai Ekonomi Produk Es Krim Naga Merah
}

\section{The Effect of Soymilk Substitution and Mocaf (Modified Cassava Flour) to the Acceptance, Fiber Content, and Product Economic Value of Red Dragon Ice Cream}

\author{
Santi Kusumastuti*1, Merryana Adriani ${ }^{1}$
}

\begin{abstract}
ABSTRAK
Latar Belakang: Es krim merupakan salah satu makanan selingan favorit masyarakat yang terbuat dari campuran susu. Es krim yang terdapat di pasaran (komersil) umumnya mengandung energi, karbohidrat, protein, lemak dan serat. Kandungan serat pada es krim rata-rata hanya 1 gram per kemasan. Suatu produk dikatakan mengandung serat yang tinggi jika mengandung 5 gram per 100 gram bahan padat sehingga diperlukan inovasi baru pada produk es krim untuk meningkatkan kandungan gizinya terutama serat. Susu kedelai dan tepung Mocaf (Modified Cassava Flour) merupakan bahan pangan yang kaya serat. Substitusi susu kedelai dan dan tepung Mocaf diharapkan dapat meningkatkan kandungan serat yang ada dalam formula es krim dibandingkan dengan es krim di pasaran.

Tujuan: Penelitian ini bertujuan untuk mengetahui daya terima, kandungan serat dan nilai ekonomi es krim naga merah dengan proporsi susu kedelai dan dan tepung Mocaf.

Metode: Metode yang digunakan dalam penelitian ini adalah eksperimental dengan rancangan penelitian Rancangan Acak Lengkap (RAL dan terdapat 7 formula yang akan diuji organoleptik kepada 3 panelis terbatas dan 3 formula terbaik kepada 30 panelis tidak terlatih. Kadar serat diperoleh dari hasil perhitungan DKBM dan uji laboratorium dengan menggunakan uji proximat.

Hasil: Berdasarkan hasil uji organoleptik, formula es krim terbaik (F4) memiliki daya terima panelis yang lebih tinggi dibandingkan formula es krim lainnya. Hasil uji laboratorium menunjukkan kandungan serat pada formula es krim F4 sebesar 18,2 gram/50 gram es krim.

Kesimpulan: Es krim dengan proporsi susu kedelai dan tepung mocaf memiliki daya terima yang baik dan memiliki kandungan serat lebih tinggi bila dibandingkan dengan es krim komersil.
\end{abstract}

Kata kunci: es krim, nilai ekonomi, serat, susu kedelai , tepung mocaf 


\title{
ABSTRACT
}

Background: Ice cream is one of the favourite desserts made from a mixture of milk. Commercial ice cream contains energy, carbohydrates, protein, fat and fiber. The fiber content in it is usually 1 gram per 50 grams serving. The fiber content is relatively low because food categorized as high fiber if it has 5 grams per 100 gram products. Therefore, a new innovation to improve its fiber content is required. Soymilk and Mocaf Flour are type of food with high fiber content that possible to be added in ice cream.

Objective: The purpose of this research was to determine the acceptability, fiber content and food cost in ice cream.

Methods: This was true experimental research with Complete Random Design (CRD) and there are 7 formulas to be tested to 3 limited panelists and 3 best formulas to 30 non trained panelists. Fiber content was calculated using Indonesia Food Composition Database and also analyzed by proximate test in laboratory.

Results: The result showed that formula 4 had the highest score than other formulas. Laboratory result showed fiber content in formula 4 was 18.2 grams per 50 grams ice cream.

Conclusion: The ice cream with proportion of soymilk and Mocaf flour has a good acceptability and higher fiber content compared to commercial ice cream.

Keywords: ice cream, economic value, fiber, soymilk, mocaf

\author{
*Koresponden: \\ sntksm@gmail.com \\ ${ }^{1}$ (Departemen Gizi Kesehatan, Fakultas \\ Kesehatan Masyarakat, Universitas Airlangga, \\ Surabaya Kode Pos, Indonesia)
}




\section{PENDAHULUAN}

Pangan fungsional adalah produk makanan segar ataupun olahan yang bukan hanya memberikan rasa kenyang namun juga memberi keuntungan lain pada tubuh yang meningkatkan kesehatan dan dapat mengurangi resiko penyakit pada manusia ${ }^{1}$. Salah satu produk makanan yang dikembangkan untuk memenuhi kebutuhan pangan fungsional adalah makanan ringan, kudapan ataupun jajanan. Makanan ringan, kudapan atau jajanan tidak dapat lagi dipisahkan dengan kebutuhan masyarakat saat ini. Kudapan menyumbang zat gizi sebesar $10-20 \%$ dari kebutuhan energi dalam sehari. Konsumsi makanan ringan yang terlalu berlebih akan tidak baik kedepannya karena tidak memberi kontribusi zat gizi yang beragam.

Es krim merupakan salah satu jenis kudapan yang disukai masyarakat dengan segala umur. Es krim adalah makanan beku dibuat dengan cara membekukan campuran produk susu, gula, penstabil, pengemulsi dan bahan lainnya yang telah melewati proses pasteurisasi dan homogenisasi ${ }^{2}$. Konsumsi es krim di Indonesia merupakan yang tertinggi di Asia Tenggara yaitu sebesar 158 juta liter/tahun ${ }^{3}$. Faktor utama dalam pertumbuhan konsumsi es krim adalah kondisi cuaca di Indonesia yang panas dan pertumbuhan jumlah penduduk yang diikuti dengan peningkatan daya beli,. Es krim kaya akan lemak, gula, fosfor, zinc, vitamin A, D, B12, asam amino, dan asam pantonenat. Lemak dari es krim dapat mempengaruhi otak manusia mengirim pesan ke sel-sel tubuh untuk mengabaikan sinyal hormon penekan selera makan, sehingga es krim dapat membuat otak manusia agar tidak berhenti makan ${ }^{4}$. Konsumsi es krim yang berlebihan dapat memicu terjadinya obesitas karena tingginya kandungan lemak di dalam es krim.

Es krim yang terdapat dipasaran merupakan jenis es krim yang banyak mengandung energi dan lemak. Produk yang terdapat dipasaran hanya mengandung serat sebesar 0,8-1 gram per 1 cup ( $237 \mathrm{ml}$ ) es $\mathrm{krim}^{5}$ Suatu produk dapat mengklaim mengandung serat yang tinggi jika mengandung 5 gram serat per 100 gram bahan padat atau $100 \mathrm{ml}$ bahan cair ${ }^{6}$. Kebutuhan serat yang harus dicukupi tubuh manusia dalam sehari ratarata sekitar $30 \mathrm{gram}^{7}$. Serat memiliki peranan penting bagi kesehatan tubuh, terutama dalam proses pencernaan makanan dalam tubuh $^{8}$. Bahan pangan tinggi serat dapat mempercepat transit time (kecepatan residu meninggalkan saluran pencernaan) yang pendek yaitu selama 14-24 jam dan cenderung membuat buang air besar lebih teratur ${ }^{9}$. Melihat pentingnya kebutuhan serat bagi tubuh dan rendahnya asupan serat di Indonesia, dibutuhkan suatu upaya untuk meningkat jumlah asupan serat pada masyarakat. Salah satu pangan yang memiliki serat yang tinggi adalah susu kedelai dan tepung Mocaf (Modified Cassava Flour).

Di Indonesia, kacang kedelai banyak dikonsumsi oleh masyarakat dalam bentuk olahan tempe, tahu dan diolah menjadi susu. Namun susu kedelai kurang begitu disukai masyarakat karena memiliki aroma yang langu. Bau langu diakibatkan oleh aktivitas enzim lipoksigenase yang ada dalam biji kedelai. Enzim tersebut menghasilkan etil fenil keton yang menyebabkan rasa khas dan bau langu ${ }^{10}$. Susu kedelai dipilih sebagai bahan substitusi susu sapi diperkenankan untuk orang-orang yang mengidap intoleransi laktosa agar tetap dapat mengkonsumsi es krim. Susu kedelai mengandung serat sebesar $3 \mathrm{~g} / 100 \mathrm{~g}$ sehingga dapat memenuhi $10 \%$ kebutuhan serat sehari ${ }^{11}$. Tepung Mocaf (Modified Cassava Flour) merupakan tepung olahan singkong yang difermentasi. Penggunaan tepung Mocaf saat ini masih belum banyak dikenal masyarakat. Tepung Mocaf mengandung serat sebesar 2,5g/100g. Karakteristik tepung Mocaf (Modified Cassava Flour )yaitu memiliki viskositas lebih tinggi dan mudah larut dibandingkan jenis tepung lainnya ${ }^{12}$. Buah naga merah merupakan buah yang memiliki rasa manis dan khasiat yang baik untuk tubuh. Buah naga merah mengandung antioksidan betalain yang memenuhi kriteria sebagai pemberi warna alami dalam pembuatan es krim sehingga aman untuk dikonsumsi ${ }^{13}$.

Pada penelitian ini substitusi susu kedelai dan tepung Mocaf (Modified Cassava Flour) dalam 
pembuatan es krim bertujuan untuk mengetahui daya terima panelis, kandungan serat dan nilai ekonomi terhadap produk es krim naga merah. Produk yang dihasilkan diharapkan dapat menjadi alternative kudapan sehat bagi masyarakat.

\section{METODE}

Alat yang digunakan dalam pembuatan es krim adalah mangkuk, timbangan digital, sendok makan, alat pengaduk (twisk), panci kecil dan gelas ukur. Bahan utama yang digunakan adalah susu kedelai dan tepung Mocaf (Modified Cassava Flour). Kacang kedelai (Glycine max) yang digunakan dalam pembuatan es krim menggunakan kacang kedelai (Glycine max) berwarna putih tulang pada bijinya dan kulit berwarna kuning muda yang masih baru dan utuh, yang memiliki aroma khas kacang kedelai dan terbebas dari benda asing. Tepung Mocaf (Modified Cassava Flour) yang digunakan adalah tepung bermerk "Ladang Lima". Tepung ini memiliki karakteristik yang sama dengan tepung maizena yaitu bertekstur halus dan berwarna putih. Sedangkan buah Naga Merah yang digunakan adalah sebanyak 75 gram untuk setiap resep pembuatan. Buah Naga Merah dipilih berdasarkan warna kulit dan sisik yang berawarna merah muda.

Penelitian ini menggunakan metode eksperimental. Rancangan penelitian yang digunakan adalah Rancangan Acak Lengkap (RAL) yang terdiri dari 6 (enam) perlakuan. Proporsi susu kedelai dan tepung mocaf yang digunakan dapat dilihat pada tabel 1 . Pembuatan produk es krim naga merah diawali dengan persiapan bahan yaitu menimbang semua bahan terlebih dahulu yang meliputi tepung maizena, tepung Mocaf, susu sapi, susu kedelai, buah naga merah, gula, ovalet, gelatin dan vanilli. Semua bahan tersebut dicampur di dalam panci. Adonan dimasak dengan pemanasan sampai mengental. Jika adonan sudah mulai mengental dan padat, angkat adonan dan pindahkan ke wadah, tunggu sampai adonan dingin. Setelah adonan dingin, masukkan ke dalam freezer hingga membeku ( $\pm 8 \mathrm{jam}$ ). Tim ovalet dengan sedikit air kemudian masukkan dalam kulkas ( \pm 10 menit). Hancurkan adonan yang sudah membeku menggunakan mixer dan masukkan ovalet yang telah dicampurkan dengan sedikit air. Selama proses pengadukan, hancurkan buah naga merah yang telah ditimbang menjadi serpihan halus, kemudian masukkan ke dalam campuran adonan secara perlahan. Mixer adonan sampai mengembang ( \pm 45 menit). Pindahkan adonan kembali ke wadah yang terlah dipersiapkan. Masukkan adonan tersebut ke dalam freezer sampai beku.

Uji tingkat kesukaan dengan cara sebagai berikut: terdiri dari 3 panelis terbatas yang berasal dari Dosen Gizi Fakultas Kesehatan Masyarakat Universitas Airlangga dan 30 panelis tidak terlatih yang berasal dari mahasiswi dan mahasiswa Fakultas Kesehatan Masyarakat Universitas Airlangga. Ketujuh sampel produk diberikan kepada panelis dengan komposisi bahan yang berbeda-beda. Tujuh formula yang diujikan terdiri dari 6 formula perlakuan dan 1 formula kontrol. Formula kontrol adalah formula dasar pembuatan es krim naga merah tanpa substitusi susu kedelai dan tepung Mocaf. Tujuh formula diujikan pada panelis terbatas untuk mendapatkan tiga formula terbaik yang kemudian diujikan pada panelis tidak terlatih.

Tabel 1. Proporsi Susu Kedelai dan Tepung Mocaf

\begin{tabular}{lcc}
\hline Formula & Susu Kedelai & Tepung Mocaf \\
\hline F1 & $20 \%$ & $25 \%$ \\
F2 & $20 \%$ & $50 \%$ \\
F3 & $40 \%$ & $25 \%$ \\
F4 & $40 \%$ & $50 \%$ \\
F5 & $80 \%$ & $25 \%$ \\
F6 & $80 \%$ & $50 \%$ \\
\hline
\end{tabular}

Formula es krim terbaik yang didapatkan dari hasil penelitian terhadap daya terima panelis terhadap es krim dengan karakteristik warna, aroma, tekstur dan rasa berdasarkan analisis deskriptif dari rata-rata skor tertinggi dan berdasarkan hasil uji laboratorium untuk kandungan serat menggunakan uji proximat. Pada penelitian ini telah disetujui oleh komisi etik Fakultas Kesehatan Masyarakat Universitas Airlangga dengan no 302-KEPK. 


\section{HASIL DAN PEMBAHASAN}

\section{Daya Terima Panelis}

Uji organoleptik secara keseluruhan kepada panelis yang terdiri dari 3 panelis terbatas (dosen Gizi Fakultas Kesehatan Masyarakat Universitas Airlangga) dan 30 panelis tidak terlatih (Mahasiswa dan mahasiswi Fakultas Kesehatan Masyarakat Universitas Airlangga) dengan penilaian terhadap karakteristik warna, aroma, tekstur dan rasa pada es krim naga merah substitusi susu kedelai dan tepung mocaf. Hasil uji organoleptik secara keseluruhan dapat dilihat pada Gambar 1.

\section{Warna}

Tabel 2 menunjukkan bahwa warna es krim yang memiliki nilai tertinggi dan paling disukai panelis adalah formula es krim F4 (4) dengan komposisi $40 \%$ susu kedelai dan50\% tepung Mocaf (Modified Cassava Flour). Warna adalah salah satu faktor yang berpengaruh dan menentukan apakah suatu produk dinilai enak, bergizi dan tekstur sangat baik $^{13}$. Suatu produk tidak akan dimakan apabila memiliki warna yang kurang sedap dipandang atau menyimpang dari warna yang seharusnya. Formula yang diproporsikan substitusi susu kedelai dan tepung mocaf pada es krim berwarna pink keunguan. Penyebab suatu bahan makanan berwarna yaitu akibat pigmen, reaksi karamelisasi, reaksi maillard, reaksi oksidasi dan pewarna aditif ${ }^{14}$. Warna merah muda keunguan pada es krim disebabkan oleh Buah naga merah juga mengandung zat warna merah alami yang dijadikan sebagai pewarna makanan alami sehingga aman untuk dikonsumsi ${ }^{15}$. Zat warna tersebut adalah antosianin. Antosianin adalah suatu zat pewarna yang berperan sebagai pewarna alami dan senyawa yang memiliki aktivitas antioksidan. Semakin banyak komposisi susu kedelai akan semakin menghasilkan warna es krim yang gelap dan banyaknya komposisi susu sapi juga dapat menghasilkan warna es krim yang pucat sehingga kurang menarik. Penerimaan warna pada suatu makanan tergantung dari faktor alami, geografi dan aspek sosial masyarakat (panelis) ${ }^{13}$.

\section{Aroma}

Aroma dari suatu produk menentukan bagaimana rasa dari suatu produk. Proses pemasakan dengan pemanasan tinggi menghasilkan aroma yang kuat ${ }^{16}$. Hasil penelitian menunjukkan formula es krim F4 memiliki nilai sebesar 3,2 dan formula es krim F2 dan F3 juga memiliki nilai yang sama. Menurut panelis aroma dari formula es krim

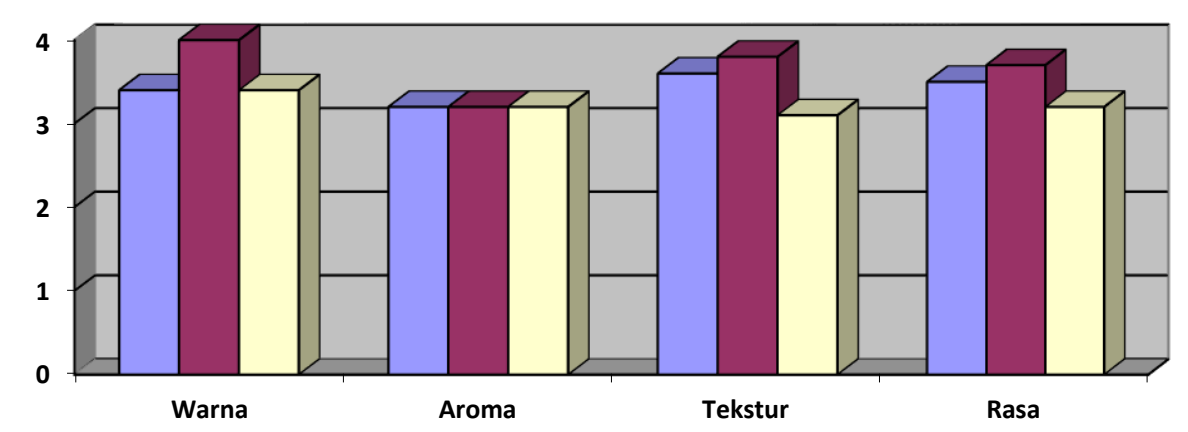

Gambar 1. Diagram Batang Rata-rata Penilaian Organoleptik Panelis Tidak Terlatih Terhadap Es Krim Naga Merah

Keterangan:

$\mathrm{F} 2=20 \%$ susu kedelai, $50 \%$ tepung mocaf

$\mathrm{F} 4=40 \%$ susu kedelai, $50 \%$ tepung mocaf

$\mathrm{F} 3=40 \%$ susu kedelai, $25 \%$ tepung mocaf 
F2, F3 dan F4 masih dapat diterima dan tidak mengganggu pada saat dikonsumsi. Meski formulanya berbeda, namun aroma yang dihasilkan pada produk es krim hampir memiliki kesamaan yaitu mengandung bau langu. Penyebab langu ( beany flavour) adalah senyawa yang mengandung gugus karbonil yang bersifat volatil, seperti $\mathrm{n}$-heksanal. Senyawa ini terbentuk sebagai hasil oksidasi asam lemak tidak jenuh yang terdapat pada biji kedelai (terutama linoleat) akibat aktivitas enzim lipoksigenase. Aroma khas langu dapat menurunkan daya terima produk, sehingga untuk menyiasati bau langu pada formulasi es krim ditambahkan perisa vanilli. Aroma vanilli banyak digunakan dalam industri makanan, minuman maupun kosmetika. Tanaman vanili (Vanilla planifolia) merupakan salah satu tanaman rempah yang bernilai ekonomi cukup tinggi. Tanaman vanilli digunakan untuk bahan penyegar, penyedap dan pengharum makanan, gula-gula, ice cream, minuman, bahan obat-obatan ${ }^{17}$.

\section{Tekstur}

Tekstur pada formula es krim F4 memiliki nilai sebesar 3,8 yang artinya panelis menyukai formula tersebut. Perbandingan susu kedelai dan tepung mocaf tidak terlalu mempengaruhi tekstur es krim formula dibandingkan dengan es krim yang dijual di pasaran. Hanya saja ada sedikit kristalisasi yang diakibatkan rendahnya kandungan lemak dalam es krim. Tekstur yang lembut juga dipengaruhi oleh kondisi bahan yang dicampurkan, cara pengolahan dan penyimpanan ${ }^{18}$. Tekstur es krim bergantung dari ukuran, bentuk dan ukuran partikel padatan penyusun es krim. Tekstur yang ideal bagi es krim adalah tekstur yang sangat halus dan ukuran partikel padatan yang sangat kecil sehingga tidak terdeteksi dalam mulut ${ }^{19}$. Penggunaan bahan penstabil pada pembuatan es krim merupakan koloid hidrofilik yang dapat menurunkan konsentrasi air bebas dengan menyerap air tersebut sehingga akan mengurangi kristalisasi es, memperkecil kristal es, dan dapat meningkatkan kehalusan tekstur yang mempengaruhi tekstur akhir produk es krim yang dihasilkan ${ }^{20}$, sehingga semakin kecil kristal es yang terbentuk, es krim akan tahan terhadap suhu ruang dan tekstur es krim juga akan lebih halus, sebaliknya semakin besar kristal es yang terbentuk maka es krim akan cepat meleleh dan tekstur menjadi lebih kasar.

\section{Rasa}

Suatu produk makanan tidak hanya terdiri dari satu kelompok rasa saja, melainkan gabungan dari berbagai macam rasa yang terpadu sehingga menghasilkan rasa yang enak $^{13}$. Rasa adalah salah satu faktor yang sangat mempengarui bagaimana suatu produk dapat diterima masyarakat. Rasa pada formula es krim F4 memiliki nilai sebesar 3,7. Perbandingan komposisi susu kedelai dan tepung mocaf yang pas membuat rasa es krim disukai panelis. Rasa ini mewakili dari bahan baku utama yang merupakan campuran susu kedelai $40 \%$ dan tepung mocaf $50 \%$. Rasa manis pada es krim lebih dominan disebabkan adanya penambahan gula dan buah naga merah. Penambahkan rasa pada es krim dipengaruhi oleh bahan-bahan penyusun pada pembuatan es krim yaitu bahan baku, lemak susu, gula dan penstabili ${ }^{21}$. Berdasarkan uji organoleptik, penilaian rasa es krim yang memiliki nilai terendah adalah formula es krim F3 $(3,1)$ dengan komposisi $40 \%$ susu kedelai dan $25 \%$ tepung mocaf. Menurut panelis, formula es krim F3 memiliki rasa yang floury sehingga menimbulkan kesan tidak enak saat dikonsumsi. Buah naga merah berpengaruh terhadap kualitas rasa (manis) pada es krim ${ }^{22}$. Hal ini terjadi karena buah naga merah memiliki rasa yang manis dan legit. Dalam pembuatan es krim gula berfungsi sebagai bahan pemanis ${ }^{13}$. Penambahan bahan dalam pembuatan es krim sangat mempengaruhi cita rasa es krim ${ }^{17}$.

Daya terima dari ketiga formula es krim terpilih berdasarkan rata-rata keseluruhan formula es krim, panelis memilih formula es krim F4 (40\% susu kedelai dan 50\% tepung mocaf) dengan nilai sebesar 3,7 yang berarti disukai panelis.

\section{Kandungan Serat}

Hasil uji laboratorium dan hasil perhitungan DKBM (Daftar Komposisi Bahan Makanan) kandungan serat pada es krim F4 dapat dilihat pada tabel 3. 
Tabel 2. Kandungan Serat pada Formula Es Krim F4

\begin{tabular}{lcc} 
& Hasil & F4 \\
\hline Perhitungan DKBM & Per $100 \mathrm{~g}$ & $2,10 \mathrm{~g}$ \\
Hasil Uji Laboratorium & Per $50 \mathrm{~g}$ (per takaran saji) & $1,05 \mathrm{~g}$ \\
& Per $100 \mathrm{~g}$ & $36,40 \mathrm{~g}$ \\
\hline
\end{tabular}

Keterangan : Hasil Perhitungan DKBM dan Uji Laboratorium

Hasil perhitungan DKBM dan uji laboraturium terhadap formula es krim F4 per 100 gram dan per porsi (50 gram) menunjukkan bahwa kandungan gizi (serat) menurut perhitungan DKBM pada formula es krim F4 per 100 gram yaitu sebesar 2,10 gram dan per porsi (50 gram) kandungan gizi (serat) es krim F4 yaitu sebesar 1,05 gram. Sedangkan menurut hasil uji laboratorium kandungan serat pada formula es krim per 100 gram yaitu sebesar 36,40 gram dan per porsi (50 gram) kandungan gizi (serat) es krim F4 yaitu sebesar 18,02 gram. Peningkatan kadar serat dikarenakan adanya proses pengolahan dengan suhu tinggi pada pembuatan adonan es krim. Pemberian panas pada pati akan meningkatkan kadar serat pada bahan pati tersebut. Bahan pati yang dimaksud adalah singkong sebagai bahan utama pembuatan tepung Mocaf ${ }^{16}$.

Es krim merupakan salah satu makanan yang bernilai gizi tinggi namun rendah serat yaitu $1 \%$ serat $^{23}$. Sumbangan nilai gizi terbesar pada es krim berasal dari bahan baku dasar yaitu susu. Oleh karena itu es krim memiliki nilai gizi tinggi dibandingkan dengan jenis minuman lainnya. Jika dibandingkan dengan es krim komersil kandungan gizi (serat) pada formula es krim pada penelitian ini mengandung serat cukup tinggi. Serat yang tinggi didapatkan dari susu kedelai dan tepung Mocaf. Susu kedelai mengandung serat sebesar $3 \mathrm{~g} / 100 \mathrm{~g}$ sehingga dapat memenuhi $10 \%$ kebutuhan serat sehari ${ }^{11}$. sedangkan tepung Mocaf mengandung serat sebesar $2,5 \mathrm{~g} / 100 \mathrm{~g}$.

Pada penelitian ini, formula es krim terbaik F4 dengan proporsi $40 \%$ susu kedelai dan $50 \%$ tepung mocaf memiliki kelebihan dari segi kandungan serat. Kandungan serat es krim naga merah substitusi susu kedelai dan tepung per takaran saji (50 gram) berdasarkan hasil uji laboratorium yaitu sebesar 18,2 gram sehingga untuk memenuhi kebutuhan serat per hari maka konsumen harus mengonsumsi es krim sebanyak $1 / 3$ porsi es krim (15 gram).

\section{Nilai Ekonomi}

Hasil perhitungan nilai ekonomi (food cost) berdasarkan perhitungan peneliti pada es krim F4 dapat dilihat pada tabel 4.

Tabel 3. Nilai Ekonomi pada Es Krim F4

\begin{tabular}{lll}
\hline & Formula & Harga \\
\hline F4 & Cost & Rp. 3.418,00 \\
& Food Cost (60\%) & Rp. 5.469,00 \\
\hline Keterangan: Hasil Perhitungan & cost (harga riil \\
bahan) dan food cost (dengan keuntungan 60\%).
\end{tabular}

Hasil perhitungan menunjukkan bahwa pada es krim formula F4 harga riil keseluruhan bahan memiliki harga $\mathrm{Rp}$. 3.418,00 sedangkan pada food cost untuk dijual di pasaran dengan keuntungan $60 \%$ memiliki harga Rp. 5.469,00. Hasil perhitungan ini harga tidak termasuk listrik, bahan bakar dan tenaga dalam pembuatan es krim. Es krim komersil sejenis berharga Rp. $4.000,00$ per 50 gram es krim (per takaran saji). Food cost adalah pembiayaan secara langsung terhadap bahan-bahan utama yang digunakan untuk memproduksi suatu makanan atau minuman dengan kata lain yaitu bahan baku langsung makanan dan tidak termasuk biaya tetapnya (overhead) seperti gaji, listrik, air dan sebagainya. Harga pokok makanan adalah seluruh biaya bahan yang dikonsumsi sesuai dengan resep baku selama proses pengolahan sampai makanan tersebut siap disajikan untuk dikonsumsi oleh tamu atau pelanggan ${ }^{24}$. 
Prosentase ideal suatu makanan berada diantara 30-60\%. Apabila dibandingkan dengan es krim komersil, harga es krim sehat memiliki harga jual yang lebih tinggi. Harga jual yang lebih tinggi dipengaruhi oleh tingginya senyawa bioaktif yang terkandung dalam produk es krim naga merah sehingga dapat berfungsi sebagai pangan fungsional. Namun demikian es krim formula F4 lebih unggul dikarenakan memiliki kandungan serat yang lebih unggul dibandingkan dengan es krim komersil.

\section{KESIMPULAN}

Pengaruh substitusi susu kedelai dan tepung mocaf pada produk es krim naga merah didapat hasil bahwa panelis lebih memilih formula es krim F4 ( $40 \%$ susu kedelai dan 50\% tepung mocaf) sebagai formula terbaik. Hasil Perhitungan DKBM menunjukkan kandungan gizi (serat) es krim F4 per porsi (50 gram) yaitu sebesar 1,05 gram. Sedangkan menurut hasil uji laboraturium kandungan gizi (serat) es krim F4 per porsi (50 gram) yaitu sebesar 18,2 gram. Kandungan serat pada produk inovatif ini lebih tinggi jika dibandingkan dengan produk es krim komersil yang ada di pasaran.

Nilai jual es krim formula F4 per 50 gram (per takaran saji) berdasarkan perhitungan peneliti yaitu memiliki harga pokok $\mathrm{Rp}, 3.418,00$ dan harga dengan keuntungan $60 \%$ yaitu Rp. 5.469,00. Es krim formula F4 memiliki harga jual sekitar Rp. $5.500,00$. Jika dibandingkan dengan es krim komersil, harga dari es krim modifikasi lebih tinggi.

Perlu dilakukan penelitian lebih lanjut terkait kandungan senyawa fungsional dan karakteristik fisik (kecepatan meleleh dan overrun) dari es krim naga merah dengan substitusi susu kedelai dan tepung mocaf.

\section{ACKNOWLEDGEMENT}

Penulis mengucapkan terima kasih kepada Dosen Gizi Fakultas Kesehatan Masyarakat Universitas Airlangga selaku panelis terbatas dan Mahasiswa Fakultas Kesehatan Masyarakat Universitas Airlangga selaku panelis tidak terlatih dalam penelitian dan teman-teman yang telah membantu dalam proses pengambilan data.

\section{REFERENSI}

1. Winarti, S. Makanan Fungsional. Yogyakarta: Graha Ilmu; 2010.

2. Darma, dkk. Pembuatan Es Krim Jagung Manis Kajian Jenis Zat Penstabil, Konsentrasi Non Dairy Cream Serta Aspek Kelayakan Finansial. Jurnal Reka Agroindustri; I: 2013.

3. Euromonitor International. 2016. Ice Cream and Frozen Desserts in Indonesia.

http://www.euromonitor.com/icecream-and-frozen-desserts-inindonesia/report. Diakses pada 20 Agustus 2017.

4. Science Daily. 2009. Ice Cream May Target The Brain Before Your Hips, UT Southwestern Study Suggests. http://www.sciencedaily.com/releases/ 2009/09/090914110533.htm. Diakses pada 20 Agustus 2017.

5. USDA (United States Department of Agricultural Research Service. Nutritive Value of Foods. 2016. https://www.ars.usda.gov/northeastarea/beltsville-md/beltsvillehuman.nutrition-researchcenter/nutrient-datalaboratory/docs/nutritive-value-offoods-home-and-garden-bulletin-no-72hg-72/. Diakses pada 20 Agustus 2017.

6. Ummi. Pemanfaatan Tepung Sorghum (Sorghum bicolor $L$ moench) pada Pembuatan Snack Bar Tinggi Serat Pangan dan Sumber Zat Besi Untuk Remaja Puteri. Skripsi. Bogor: Institut Pertanian Bogor, 2011.

7. Kemenkes Kesehatan RI. Angka Kecukupan Gizi Yang dianjurkan Bagi Bangsa Indonesia. Jakarta: Kementrian Kesehatan RI. 2013.

8. Almatsier, Sunita. Prinsip Dasar IImu Gizi. Jakarta: Gramedia; 2009.

9. Janathan. Karakteristik Fisikokimia Tepung Bekatul Serta Optimasi Formula Dan Pendugaan Umur Simpan Minuman 
Campuran Susu Skim Dan Tepung Bekatul. Skripsi. Bogor: Institut Pertanian Bogor, 2007.

10. Astawan, M. Sehat Dengan Tempe : Panduan Lengkap Menjaga Kesehatan dengan Tempe. Bogor: Dian Rakyat; 2008.

11. Departemen Kesehatan Republik Indonesia. Daftar Komposisi Bahan Makanan. 2014.

12. Hanifa. et al. Kadar Protein, Kadar Kalsium dan Kesukaan Terhadap Cita Rasa Chicken Nugget Hasil Susbtitusi Terigu dengan Mocaf dan Penambahan Tepung Tulang Rawan. Jurnal Pangan dan Gizi 2013; 04: 53-60.

13. Elastri, A. Pengaruh Substitusi Ekstrak Kulit Buah Naga Merah Terhadap Kualitas Es Krim. Skripsi. Padang: Universitas Negeri Padang, 2015.

14. Winarno, F. G. Kimia Pangan dan Gizi: Edisi Terbaru. Jakarta: PT. Gramedia Pustaka Utama; 2008.

15. Putri. Pengaruh Kadar Air Terhadap Tekstur Dan Warna Keripik. Makassar: Universitas Hasanuddin, 2012.

16. Kusumastuti, S. Pengaruh Substitusi Susu Kedelai, Tepung Mocaf, Buah Naga Merah (Hylocereus polyrhizus) Terhadap Daya Terima, Nilai Gizi dan Nilai Ekonomi Pada Es Krim. Skripsi . Surabaya : Sarjana Universitas Airlangga, 2017.

17. Helmy, Zahron. Pengolahan dan Penganekaragaman Hasil Vanili
Berdasarkan Standar Mutu Nasional. Bogor: Pusat Penelitian dan Pengembangan Perkebunan (Puslitbangbun); 2008.

18. Padaga, Masdiana dan Manik. Membuat Es Krim Yang Sehat. Surabaya: Trubus Agrisarana; 2008.

19. Dewi, R. K. Pengaruh Penambahan Limbah Aneka Buah Berserat Terhadap Daya Terima dan Kandungan Gizi Es Krim Sehat sebagai Makanan Alternatif Anak Obesitas. Skripsi. Surabaya : Sarjana Universitas Airlangga, 2011.

20. Nugroho, Y. A., \& Kusnadi, J. Aplikasi Kulit Manggis ( Garcinia Mangostana L .) Sebagai Sumber Antioksidan Pada Es Krim. Jurnal Pangan dan Agroindustri 2015; 3: 1263-1271.

21. Jumiati, V. S. J. and Y. Studi Pembuatan Es Krim Berbasis Santan Kelapa Dan Bubur Ubi Jalar Ungu. JOM. Faperta 2015; 2.

22. Adhitya, Levi. Membuat Es Krim. Jakarta: Agromedia; 2008.

23. Simanungkalit, dkk. Kajian Pembuatan Es Krim dengan Penambahan Kacang Merah (Phaseolus vulgaris L). Jurnal Penelitian Universitas Jambi Seri Sains 2016; 18: 20-26.

24. Nuada, I. W. Kalkulasi Harga Pokok Makanan (Food Cost) Harian untuk Pengendalian Biaya di Hotel. Media Bina IImiah 2013; 7: 52-59. 